NBER WORKING PAPER SERIES

\title{
KEYNES ON THE SEQUENCING OF ECONOMIC POLICY: RECOVERY AND REFORM IN 1933
}

\author{
Sebastian Edwards \\ Working Paper 24367 \\ http://www.nber.org/papers/w24367 \\ NATIONAL BUREAU OF ECONOMIC RESEARCH \\ 1050 Massachusetts Avenue \\ Cambridge, MA 02138 \\ March 2018
}

I thank Michael Poyker for his assistance. I have benefitted from conversations with Michael Bordo, Leonidas Montes, and Ed Leamer. The views expressed herein are those of the author and do not necessarily reflect the views of the National Bureau of Economic Research.

NBER working papers are circulated for discussion and comment purposes. They have not been peer-reviewed or been subject to the review by the NBER Board of Directors that accompanies official NBER publications.

(C) 2018 by Sebastian Edwards. All rights reserved. Short sections of text, not to exceed two paragraphs, may be quoted without explicit permission provided that full credit, including () notice, is given to the source. 
Keynes on the Sequencing of Economic Policy: Recovery and Reform in 1933

Sebastian Edwards

NBER Working Paper No. 24367

March 2018

JEL No. B21,B22,B26,B27,E31,F31,N12,N22

\begin{abstract}
$\underline{\text { ABSTRACT }}$
On December 31 1933, The New York Times published an open letter from John Maynard Keynes to President Franklin D. Roosevelt. In it Keynes encouraged FDR to expand public works through government borrowing. He also criticized FDR's exchange rate policy, and argued that there was a need for lower long-term interest rates. But perhaps the most interesting feature of this letter is that Keynes made comments on the sequencing and speed of economic policies. He argued that "recovery" policies should precede "reform" measures. In this paper I analyze this particular aspect of the open letter, and I argue that for Keynes exchange rate stability was a key component of what he considered to be the appropriate order of policy. I also provide a comparison between Keynes's views on sequencing and those developed in the 1980s and 1990s.
\end{abstract}

Sebastian Edwards

UCLA Anderson Graduate School of Management

110 Westwood Plaza, Suite C508

Box 951481

Los Angeles, CA 90095-1481

and NBER

sebastian.edwards@anderson.ucla.edu 


\section{Introduction}

On September 24 1933, Felix Frankfurter, the prominent Harvard law professor, sailed in the steamer Britannic to London. According to The New York Times, the trip had a double purpose: on the one hand Frankfurter was to be the Eastman Professor at Oxford, and on the other he was "on an unofficial presidential mission, assisting the Chief Executive [President Franklin Delano Roosevelt] in keeping abreast of affairs, particularly financial matters all over the world.”1 During his year-long stay in the United Kingdom, Frankfurter met all sorts of people, gave a number of lectures, and cemented friendships with some of the most influential intellectuals of the time, including Isaiah Berlin and John Maynard Keynes.

On December 6 1933, Frankfurter went to Cambridge, where he was a guest of Keynes for King's Founder's Feast. During the visit the conversation touched on many topics, including the economic experiments undertaken by the new U.S. administration. ${ }^{2}$ A few days later the Harvard professor wrote to Keynes and suggested that he penned an article for a U.S. newspaper giving his opinion about President Roosevelt’s economic policies. In particular, he wanted Keynes to support an expansion of public works. Frankfurter wrote: ${ }^{3}$

I do hope you'll find it convenient to write the kind of letter that we sketched in our talk for transmission to the president. For he is 'the trustee of experimentation' and I know that formulated directions from you may greatly help matters.

On December 12, Frankfurter wrote to President Roosevelt and informed him about his visit to Cambridge. Four days later, on December 16, he told the president that Keynes had written an open letter, which would be published by The New York Times on December 31, 1933. Frankfurter wrote: "So that you may see what he has to say before it is published, Keynes this morning sent me the enclosed, which I hasten to get off directly to you through Miss LeHand (without forwarding it through the pouch) in the hope that it may catch the Bremen which leaves tonight." 4

\footnotetext{
${ }^{1}$ The New York Times, "Frankfurter sails; Held Roosevelt Aide," September 25, 1933, page 2. According to Lash (1975, p. 53), during the early years of the Roosevelt administration, Frankfurter not only dispensed advice to the president, but he also acted as "a one-man recruiting agency for the New Deal." In 1939 Roosevelt appointed Frankfurter to the U.S. Supreme Court, where he served until 1962.

${ }^{2}$ Roosevelt had been inaugurated on March 4 1933. See Section 2 for some historical background.

${ }^{3}$ Moggridge (1992, p. 580).

${ }^{4}$ Freedman (1967, p. 177). Miss LeHand was FDR's personal secretary. Frankfurter was also the intermediary of a private letter by a group of Oxford dons to Roosevelt. That letter was signed by Roy Harrod, James Meade, and W.M. Allen, among other. See Freedman (1967, p. 168-173).
} 
The open letter was published on Sunday, December 31, with the title "From Keynes to Roosevelt: Our recovery plan assayed.” The only difference between the published version and the one sent by Frankfurter to the president was that the NYT included nine headings. The letter took almost a full page of the paper. There were two photographs, one of Keynes, and one of a "slum clearance,” with the caption, "Public works: the way out?” A somewhat shorter version was published in The Times of London on January 2, 1934 (p. 11) under the title, "Mr. Roosevelt's experiments: the dual policies, reconstruction and recovery.” This version also included headings, although they were different from those in The New York Times. ${ }^{5}$ In the letter Keynes provided an assessment of the administration's policies, and stated that there was an important difference between "recovery" and "reform.” He pointed out that the former was more urgent than the latter, and he was critical of the Roosevelt administration for not defining priorities, and for pushing "reform" policies too fast. He asserted that an increase in government loan-expenditures was key to get the recovery going, and to move the nation out of the Great Depression. He commented on FDR's gold policy - including on the U.S. abandonment of the gold standard in April 1933 -, and he was critical of the way in which monetary policy had been conducted. ${ }^{6}$

Throughout the years, a number of authors have referred to the open letter, but there have been no attempts to analyze it in detail, or to use data to discuss Keynes's main assertions - see Section 3 for a review of the literature. ${ }^{7}$ The purpose of this paper is to deal with this omission, and to analyze in some detail Keynes's advice to the President in the open letter. In particular, I discuss Keynes's references to the appropriate "sequencing” of economic policy - the order in which "recovery" and "reform" should be undertaken-, and his criticism of the way the Roosevelt administration proceeded during its first nine months. Issues related to sequencing and speed have attained significance in policy debates at different times in history. For instance, they became particularly important during the late 1980s and early 1990s, when a large number of nations embarked on economic reforms in Latin America, Asia, and in the former Soviet bloc. During this period authors such as McKinnon (1982, 1993), Krueger (1986), Harberger (1986), Mussa (1986), Edwards (1990), and Mundell (1995) wrote on the subject. Interestingly, during those years, when academics and economist at the multilateral institutions - the International

\footnotetext{
${ }^{5}$ All quotes from the letter in this paper are taken from this version of the letter. The New York Times (NYT), December 31, 1933, p. 2 XX. The letter is reproduced in Keynes's Collected Works, JMK XXI (1982), p. 289-297. The Times of London version is in JMK XXI (1982), p. 297-304.

${ }^{6}$ This was not the first time Keynes opined on the effectiveness of policies to fight the Depression in foreign countries. In a lengthy article published in the Melbourne Herald on June 27 1932, he discussed in great detail Australia's adjustment policies, including the devaluation of the currency and the cut in civil servants' salaries. For details, see Markwell (2000).

${ }^{7}$ The only exception is Edwards (2017c), where an econometric analysis of the exchange rate and gold policy aspects of the letter is provided.
} 
Monetary Fund and the World Bank - discussed issues related to sequencing and speed, no references were made to Keynes views on the subject.

The rest of the paper is organized as follows: In Section 2, I provide some historical background on the state of the U.S. economy in 1933. Section 3 contains a summary and deconstruction of the open letter, and a review of the literature that has discussed it throughout the years. I consider academic works as well as memoirs and diaries from individuals that had policy responsibilities in 1933. In Section 4, which is the core of the paper, I deal with Keynes's views on sequencing. The Section is divided into two parts: I first provide an in depth analysis of Keynes's thoughts on the appropriate order and speed of policy. I then argue that for Keynes exchange rates stability, as defined in The means to prosperity - a pamphlet also published earlier in 1933 - was a central component of his views of the correct sequencing. Finally, in Section 5 I provide some concluding remarks, including some comments on how Keynes's views on sequencing are related to those developed in the 1980s and 1990s when a score of countries moved towards liberalizing and stabilizing their economies.

\section{Historical background}

When Franklin D. Roosevelt was inaugurated as president on March 4 1933, the U.S. was in the fourth year of the worst economic crisis it had ever faced. The 1929-33 slump was several times deeper and more devastating than anything America had seen before. Between 1929 and 1932, Gross Domestic Product (GDP) measured in current dollars dropped by more than 50\%, production of durable goods, including automobiles, declined by $81 \%$, and the value of agricultural production was down by 63\%. During the same period employment declined by almost 50\%, and the number of unemployed surpassed 15 million. Those who still had jobs earned much less than during 1929: according to the Federal Reserve, average wage rates declined by $67 \%$, and cash income in the rural sector was down by more than $70 \%{ }^{8}$ The United States had had recessions and financial panics in the past, but nothing resembled this. The most recent slump had happened in 1921-1923, but in every single category that downturn had been milder and the recovery faster. ${ }^{9}$ The panics of 1907 and 1873 had been serious, but they were rather small disturbances when compared to what President Herbert Hoover called the Great Depression. ${ }^{10}$

\footnotetext{
${ }^{8}$ These data compare, for each variable, the peak and the trough throughout the cycle. The data are from "Historical Statistics of the United States: Colonial Times to 1957," and from Sachs (1934).

${ }^{9}$ See Table III in Sachs (1934) for a comparison of the 1929-33 and 1921-23 episodes. For a succinct history of financial crises from around the world see Kindelberger (1978); the modern reference is Reinhart and Rogoff (2009).

${ }^{10}$ Hoover was not the first president to use the term "depression" to refer to an economic turndown. James Monroe labeled the 1819 bank panic as a depression. For an analysis of this period, with an emphasis on the first
} 
One of the most destructive aspects of the crisis was the generalized collapse of prices. Between mid-1929 and mid-1932 the index of wholesale prices went down by approximately 70\%; during the same period the cost of living for the typical household declined by $40 \%$. Things were particularly bad in the agricultural sector, where the prices of some crops were so low that it was not worth harvesting them. A bushel of wheat that in 1919 had commanded 1.53 dollars, was sold at 13.5 cents in 1932. And the price of cotton, the commodity that Roosevelt would monitor throughout his presidency, experienced a decline from 35.34 cents per pound in 1919, to 6.52 cents in 1932 - a reduction of 82 percent.

On March $5^{\text {th }}$, one day after Inauguration, President Roosevelt convened Congress for an Extraordinary Session, and the legendary "Hundred Days” began. In the early morning of March 6, a banking holiday and a gold embargo were declared. Five weeks later the nation abandoned the gold standard. However, it would take almost nine months for the dollar to be officially devalued with respect to gold. ${ }^{11}$ Between March and June, 1933, Congress passed legislation that would fundamentally alter the way the economy functioned, and set the bases for the welfare state. On May $12^{\text {th }}$ the Agricultural Adjustment Act (AAA), the Federal Emergency Relief Act, and the Tennessee Valley Authority Act were enacted into law. A few days later, on May $27^{\text {th }}$, the Securities Act of 1933 saw the light of day. During the first two weeks of June Congress continued to work at a frantic pace. On June $13^{\text {th }}$ the Homeowners Loans Act was passed, and on June $16^{\text {th }}$, the last day of the Extraordinary Session, the Glass-Steagall Banking Act, the Emergency Railroad Transportation Act, and the Farm Credit Act were passed. That same day the National Recovery Act (NRA), which introduced some elements of planning into the economy, was signed into law. During his first months in office FDR repeatedly stated that the overriding goal of his economic policies - including of the abandonment of the gold standard was to generate an increase in prices, and in particular in agricultural prices.

\section{The open letter and the literature}

\subsection{The letter: summary and deconstruction}

It is possible to divide Keynes’s letter - which has 19 paragraphs - into six different themes, each of them related to a set of policy issues of importance to the U.S. in 1933. In what follows all the quotes refer to the letter as published by The New York Times and reproduced in Volume XXI of Keynes’s Collected Works, JMK XXI (1982):

year of the Roosevelt administration and on the abandonment of the gold standard and the devaluation of the dollar, see, for example, Edwards (2018).

${ }^{11}$ On January 31 1934, the official price of the metal was set at $\$ 35$ an ounce, up from $\$ 20.67$, a price that had prevailed since 1834 . 
- $\quad$ The importance of Roosevelt's experiment: In paragraphs 1 and 19 Keynes writes that FDR's experiments are not only important for the U.S., but also for the rest of the world. Keynes opens the missive by stating that FDR is the "trustee for those... who seek to mend the evils of our condition by reasoned experiment.” The idea that Roosevelt was an experimenter was, at the time, quite widespread. In fact, and as noted above, in the communication urging Keynes to write the letter, Frankfurter referred to the new president as "the trustee of experimentation." ${ }^{12}$ Moreover, during the presidential campaign FDR had stated vehemently that experimenting in the arena of economic policy was fundamental to defeat the Depression. For instance, in the Oglethorpe speech of May 22 1932, he said: “[T]he country demands bold, persistent experimentation. It is common sense to take a method and try it: If it fails, admit it frankly and try another." 13 In the first paragraph of the open letter Keynes states that it is fundamental that FDR succeeds in his experiments. Keynes writes that if Roosevelt fails, "rational change” would be discarded, "leaving orthodoxy and revolution to fight it out." Keynes returns to this topic in the final paragraph of the open letter, where he affirms that Roosevelt success is important "to the material prosperity of the United States and the whole world.”

- $\quad$ The sequencing of policy: This subject, which is the focus of attention of this paper, is tackled in paragraphs 2 through 4. According to Keynes, FDR is "engaged on a double task, Recovery and Reform; - recovery from the slump, and the passage of those business and social reforms which are long overdue.” Keynes then points out that in his view it is important for "recovery" policies to be implemented before the policies of "reform" are put in place fully. Moreover, he argues that reform should be pursued gradually, in order not to affect confidence. His preference is that "recovery" shows some results before "reform" policies are applied with force. In the letter Keynes explicitly associates "reform" with two key policies of the Roosevelt administration: the Agricultural Adjustment Administration (AAA), whose aim was to control the acreage devoted to key crops, and the National Recovery Administration (NRA) whose purpose was to avoid cut-throat competition, and thus further declines in prices and disinflation. Keynes writes that in the reform area "haste will be injurious.” In these three paragraphs Keynes questions the wisdom of implementing recovery and reform policies simultaneously, something that, in his view, the Roosevelt administration has done during its first nine months.

\footnotetext{
${ }^{12}$ Freedman (1967, p. 177).

${ }^{13}$ Roosevelt (1938, p. 639-647), emphasis added.
} 
- $\quad$ Aggregate demand and loan-expenditures: In paragraphs 5 through 7, Keynes deals with "the technique of Recovery itself," and provides his rapidly evolving views about the functioning of the macro economy, views that he would present more fully thirty months later in The General Theory. He points out that in modern economies output is "primarily produced for sale; and the volume of output depends on the amount of purchasing power." He argues that an expansion in output would only take place if households spend more out of their incomes, firms increase investment, and/or the government creates additional incomes "through the expenditure of borrowed or printed money." He then proceeds to explain that during bad times it is very difficult for households to increase expenditures. He further points out that firms will only expand their investment during the "second wave of attacks on the slump after the tide has been turned by the expenditures of public authority." ${ }^{14}$ The combination of these two factors leaves the government as the only entity capable of contributing to a robust recovery. In paragraph 6 he writes that higher prices are "usually a symptom of rising output and employment." He then adds that in order for prices to rise it is important that the monetary authority allows that to happen, by supporting "the increased monetary turn-over." He also points out that higher prices will help debtors, by reducing the real value of their liabilities. ${ }^{15}$ In paragraph 7 he clarifies that higher prices should not be a goal by themselves. He writes: "the stimulation of output by increasing aggregate purchasing power is the right way to get prices up; and not the other way round."

- The role of public works: Paragraphs 8 through 10, and 17 expand on the points made above, by emphasizing the role of loan-expenditures in the recovery. At the beginning of paragraph 8 Keynes writes: "I lay overwhelming emphasis on the increase of national purchasing power resulting from governmental expenditure, which is financed by loans and not by taxing present incomes. Nothing else counts in comparison with this." During a major downturn only large increases in government expenditures can resuscitate the economy: "That is why war has always caused intense industrial activity.” In paragraph 9 he criticizes the Roosevelt administration for having failed to increase government expenditures during its first six months in office. ${ }^{16}$ He returns to this general subject in paragraph 17 , where he writes that it is not his role "to choose particular objects of expenditure. But preference should be

\footnotetext{
${ }^{14}$ Emphasis in the original.

15 This point had been made repeatedly by Irving Fisher.

${ }^{16}$ In fact, one of the first economic measures undertaken by the new administration was to pass the Economy Act, aimed at balancing the budget, through large government expenditure cuts. See Table 1.
} 
given to those which can be made to mature quickly on a large scale, as for example the rehabilitation of the physical condition of the railroad.”

- $\quad$ The role of monetary policy: Keynes devotes two paragraphs- 11 and 18 - to monetary policy. In paragraph 11 he refers to the Quantity Theory of Money as a “crude economic doctrine." He then points out that given the conditions in the US, it is very unlikely that monetary policy would be effective: "[T]his it is like trying to get fat by buying a larger belt... It is the most misleading thing to stress the quantity of money, which is only a limiting factor, rather than the volume of expenditure, which is the operative factor." Keynes comes back to money in the penultimate paragraph (18) where he points out that what really matters is the long-term interest rate, and suggests that the Federal Reserve tries to twist the yield curve. He tells the President: "I see no reason why you should not reduce the rate of interest in your long term government bonds to $2 \frac{1}{2} \%$ or less.” He then adds that the way to achieve this is through a policy where the Federal Reserve System "would replace its present holdings of short-dated Treasury issues by purchasing long-dated issues in exchange."

- Gold and exchange-rate policies: Keynes deals with these matters in paragraph 12 through 16 . He writes that the "exchange rate policy of a country should be entirely subservient to the aim of raising output and employment to the right level.” He then adds the sentence that many people quote - most times without having read the letter: "The recent gyrations of the dollar have looked to me more like a gold standard on the booze than the ideal managed currency of my dreams.” This was a direct criticism of the Administration's “gold buying program,” launched on October 25 1933. ${ }^{17}$ According to this plan, the government was allowed to purchase gold at prices determined periodically by the Secretary of the Treasury and the President; these prices were, almost every day, significantly higher than the world price for gold. Keynes points out that stability of the exchanges is desirable under most circumstances. This, however, does not mean that he advocates a return to the traditional gold standard. Throughout these paragraphs he summarizes his views on a new international economic order, as presented in the May 1933 pamphlet The means to prosperity.

\footnotetext{
${ }^{17}$ There were two phases for the gold buying program. Generally, the second phase, which started in late October, is singled out as "the gold buying program."
} 
The letter generated immediate reactions, both in the U.S. and in Great Britain. On January 1, 1934, the New York Times published an article with comments by three academics: Professors Raymond Moley from Columbia, Irving Fisher from Yale, and Willford I. King from New York University. ${ }^{18}$ Moley, who until a few weeks earlier had been an Assistant Secretary of State, argued that both the NRA and the AAA contributed positively to recovery. He said:

[Keynes] misses two points: First, the NRA is not primarily concerned with increasing production, but with spreading work and in the balancing production within the great fields of industry. Second, the NRA followed the AAA and was intended to help the industry to absorb the new purchasing power by agriculture provided by the AAA. The two are in balance... In the main, Mr. Keynes's constructive suggestions are sound. The trouble is he doesn't realize that most of those are already adopted. The Roosevelt program must be seen as a whole, not one aspect of it.

Irving Fisher was in general agreement with Keynes. He said: “[H]ad the NRA program been deferred six months or a year, and if it had been possible to launch the public works program more promptly, we might have been considerably farther along in our recovery. But as a matter of fact the public works program could probably not have been pushed any faster.” Professor King expressed skepticism about Keynes's views, and argued that increased government expenditure financed by borrowing was likely to crowd-out private expenditure "by exactly the same amount it is increasing public purchasing power."

Although Keynes did not answer the comments published in the U.S., he did write to the Times of London, commenting on a letter from Ian MacDonald Horobin, a Conservative M.P. Keynes's letter was published on January 8. He asserted that his was not an attack on the NRA; all he was doing was describing "these measures as reform but not recovery."19

In the New York Times letter Keynes used harsh language when describing FDR's policies: “crack brained and queer," “on the booze," "foolish application,” "set of fallacies," "crude economic doctrine," and so on. This contrasts sharply with the language used just a few months earlier, when on July 4 1933, he published in the Daily Mail a piece titled "President Roosevelt is magnificently right." ${ }^{20}$ An interesting question is what happened during those few months that prompted Keynes to change his language in such a way. The answer has to do, largely, with FDR's “gold buying program," launched in August and expanded in October. As I argue below, for Keynes, manipulating the price of gold as a way out of the Depression made little sense. It

\footnotetext{
18 "3 reply to Keynes on NRA criticism," NYT, January 1, 1934, p. 5.

${ }^{19}$ Times of London, "Mr. Roosevelt's efforts," January 8, 1934, p. 13. JMK XXI (1982), p. 304.

${ }^{20}$ JMK XXI (1982), p. 273.
} 
was a gimmick, a policy based on a statistical coincidence that got the relation between cause and effect wrong. Further, and as noted in the Section 4 of this paper, it was contrary to what he had advocated in The means to prosperity. In addition, Keynes was disappointed that the NRA and AAA had not been accompanied by an aggressive public works program.

\subsection{The literature}

Most of Keynes biographers mention the open letter in their renditions of Keynes’s life, academic work, and policy advice. None of them, however, analyzes it in detail. Harrod (1951, p. 447-8) refers to the letter within the context of the London World Monetary and Economic Conference of 1933, and the evolution of Keynes's views on the international monetary system. He states, without elaborating, that in Keynes's opinion FDR's gold buying program was based on a crude version of the quantity theory. ${ }^{21}$ He also stresses Keynes's distinction between “recovery” and "reform." However, he does not analyze why Keynes preferred a particular order of policy. In the second volume of his biography, Skidelsky (1992, p. 492-494) provides a more detailed examination of the letter. He discusses its origin, including Frankfurter's role in persuading Keynes to write it, and provides briefs comments on some of its content. Skidelsky (p. 493) emphasizes Keynes's criticism of the NRA, a program of reform disguised as recovery that "should be put into cold storage." He also points out, briefly, that Keynes believed that it was a mistake to try raising output by depreciating the currency. Moggridge (1992, p. 580-581) refers to the letter and to Keynes's views on public works and the dollar. He points out that it is unclear whether the missive influenced FDR's policies. Felix (1999, p. 243) refers to the open letter on passing, and mentions that in 1933 Keynes was renewing his friendship with Felix Frankfurter.

A number of authors who have dealt with the U.S. abandonment of the gold standard have mentioned the letter; none of them, however, has analyzed it in detail. In Ahamed's (2009) book on monetary policy in the interwar period, the anti-penultimate chapter is titled "Gold standard on the booze," a quote taken directly from the letter. The analysis touches on many policies undertaken during the first year of the Roosevelt administration. However, the letter itself is only mentioned on passing. According to Sumner (1999, p. 528 and 2015, p. 261) the letter shows that Keynes’s concern about inflation was rather high. Rauchway (2015, p. 96) argues that the letter shows that "Keynes did not seem to understand the political opposition Roosevelt faced." Dimand (1994, p. 93) deals with the letter briefly when discussing Irving Fisher’s proposal for a “compensated dollar.” Kroszner (1999, p. 9) mentions it on passing in his paper on the abrogation of the gold clauses. Edwards (2017a, p.19) refers to the letter in his discussion of the

\footnotetext{
${ }^{21}$ Keynes was wrong on this point. George F. Warren, the architect of the gold buying program, expressly pointed out in his book (With Frank A. Pearson) Prices (1933, p 128) that his approach had no relation, whatever, to the quantity theory.
} 
intellectual underpinnings of FDR's dollar policy in 1933. Some authors, including Galbraith (1984) and O'Connell (2016), mention the open letter as an early example of Keynes's belief that public works, financed by borrowing, would impact aggregate demand and employment positively. None of these authors, however, attempt to evaluate Keynes's views on policy sequencing or the dollar during late $1933 .^{22}$

The letter is not mentioned in either of the two memoirs written by FDR's adviser Raymond Moley $(1939,1966)$. This is somewhat surprising, given that Moley interacted extensively with Keynes during the London Monetary and Economic Conference of June-July 1933. In fact, Keynes helped him put together a communiqué explaining FDR's position regarding currency values and the stabilization of the exchanges. ${ }^{23}$ Rexford G. Tugwell, the only economist in the advisory group known as the Brains Trust - a group that was led by Raymond Moley -, does not mention the letter in his diaries. However, he dealt with it many years later (in 1970), in a lengthy review article where he discusses a selection of letters exchanged between President Roosevelt and Felix Frankfurter. According to Tugwell, these exchanges suggest that FDR was not particularly impressed by Keynes's recommendations; he thought that there was little new in them. Tuwell (1970, p. 103) writes: "Roosevelt was less than enthusiastic about receiving from Keynes the advice to do what he had already been doing for some time.”

James P. Warburg, another important presidential adviser during 1933, refers to the letter in his memoirs published in 1934. He focuses exclusively on Keynes's criticisms of FDR's gold and exchange rate policies. According to Warburg, "there was some mild flare-up of excitement when on the last day of the year, J. Maynard Keynes... described the 'gyrations of the dollar' under the Government manipulation as 'more like a gold standard on the booze' than and ideally managed currency." Warburg then adds that Keynes characterized as "foolish" the idea "that there is a mathematical relation between the price of gold and the price of other things." " 24 For Warburg this was an opportunity to settle a score with Professor George F. Warren, an old rival and the intellectual father of the gold-buying program. Warburg comes back to Keynes's open letter in his second volume of memoirs, published in 1964. Chapter 16 is titled "Gold standard on the booze." However, in this 13-page chapter there is no reference to Keynes's view on loan expenditures, his distinction between "recovery" and "reform," or his advice regarding the sequencing of policies; the discussion deals mostly with the London Monetary and Economic

\footnotetext{
${ }^{22}$ In his thorough volume on the discussions leading to the Bretton Woods conference Steil (2013) deals with many of the interactions between Keynes and the Roosevelt administration - including his many memos to Secretary Henry Morgenthau during World War II --, but he does not discuss in detail the NYT letter from December 1933. In his monumental oeuvre on the gold standard, Eichengreen (1991) does not discuss Keynes open letter. The letter is not mentioned in Friedman and Schwartz (1963), Temin (1976), or Meltzer (2003).

${ }^{23}$ Journalist Walter Lippmann also worked on that communique.

${ }^{24}$ Warburg $(1934$, p. 159).
} 
Conference and Keynes's views on the dollar, sterling, and the international monetary system (Warburg 1964, p. 139-152).

Keynes's open letter is not mentioned in Dean Acheson's memoirs. This is a surprise, since as Undersecretary of the Treasury Acheson was in charge of authorizing the gold-buying program that Keynes criticizes in the letter. Moreover, Acheson thought that the second phase of the program, launched on October 24 1933, was illegal, and went ahead with it only after receiving written instructions from Will Woodin, the Secretary of the Treasury. ${ }^{25}$ Herbert Feis, the only professional economist who participated in the complete deliberations that led to the gold-buying program and to the eventual official devaluation of the dollar in January 1934, does not mention Keynes’s letter in his memoirs titled “1933: Characters in Crisis.” For him, the most important event in December 1933 was that Prohibition came to an end. ${ }^{26}$ Sir Frederick Leith Ross, a Senior Adviser to the U.K.'s Treasury does not mention the letter in his extensive memoirs published in 1968, where he discusses the negotiations with his American counterparts regarding currencies and the stabilization of the exchanges (Leith-Ross 1968).

Henry Morgenthau Jr. replaced Dean Acheson as Undersecretary of the Treasury in November 1933, and was appointed Secretary on January 1 1934, one day after Keyes’s’ letter was published. He served in that post until July 1945. During his work in the Roosevelt and Truman administrations, Morgenthau kept detailed notes and an extensive diary, which has been an invaluable source for historians trying to understand the policies of the New Deal. In these diaries - which are kept in the Roosevelt Presidential Library and are now available on line -, there is no reference to Keynes's letter.

\section{Keynes on Sequencing in 1933}

\subsection{Recovery vs Reform}

Keynes's discussion of sequencing is rather narrow, and deals with only two aspects of policy: what he calls "recovery" and with "reform."27 Recovery referred to macroeconomic policies aimed at generating higher aggregate demand, raising prices, and reducing unemployment; the ultimate purpose of these policies was, of course, to end the Great Depression. Reform, on the other hand, had to do with policies geared at changing structural aspects of the U.S. economy, including efforts to rationalize resource allocation, regulate large conglomerates and trusts, improve working conditions, and coordinate supply in the agricultural sector. Other goals of the reform policies were to provide electricity to isolated rural communities, generate higher wages,

\footnotetext{
${ }^{25}$ Acheson (1965).

${ }^{26}$ Feis (1966, p. 323).

${ }^{27}$ As above, all quotes are from the open letter as published in the New York Times, as reproduced in volume XXI of the Collected Works. JMKXXI, (1982), p. 289-297.
} 
rationalize the functioning of the banking system, and implement some form of indicative planning. FDR advisers, and Brains Trust members Rexford G. Tugwell and Adolf A. Berle, had advocated many of these reform measures during the presidential campaign. ${ }^{28}$ In 1933, many of these reform policies were implemented through a variety of legislation, including the National Industrial Recovery Act and the Agricultural Adjustments Act.

In paragraph two of the open letter, Keynes wonders whether FDR and his advisers appreciate that there is an optimal sequencing of policy. Keynes writes: "We wonder whether the order of different urgencies is rightly understood, whether there is a confusion of aim, and whether some of the advice you get is not crack-brained and queer." ${ }^{29}$ He then addresses the President directly, and writes: "You are engaged on a double task, Recovery and Reform; - recovery from the slump, and the passage of those business and social reforms which are long overdue." In the third paragraph Keynes presents his concrete recommendations on sequencing and speed: "For the first [recovery], speed and quick results are essential. The second [reform] may be urgent too; but haste will be injurious, and wisdom of long-range purpose is more necessary than immediate achievement."

For Keynes, the issue is mostly political. For him, as noted, it is fundamental that the Roosevelt government does not fail in its experiments. He writes that if FDR's policies are successful "new and bolder methods will be tried everywhere, and we may date the first chapter of a new economic era from your accession to office.” In contrast, he states, failure will mean that "rational change will be gravely prejudiced throughout the world, leaving orthodoxy and revolution to fight it out.” At the center of Keynes's argument is the need for investors to regain "confidence." Confidence, in turn, will increase if the policies of the administration aimed at recovery grow in credibility and reputation - or what Keynes labels "prestige.” Only then, will FDR's experimental policies gain the full support of Congress. ${ }^{30}$ Keynes writes (emphasis added):

It will be through raising high the prestige of your administration by success in short range Recovery, that you will have the driving force to accomplish longrange Reform. On the other hand, even wise and necessary Reform may, in some respects, impede and complicate Recovery. For it will upset the confidence of the

\footnotetext{
${ }^{28}$ Rexford Tugwell was a firm believer of the benefits of implementing some kind of planning in the United States. For an analysis of the role played by the Brains Trust see Edwards (2017a). For a first person account see Tugwell (1968). 
business world and weaken their existing motives to action, before you have had time to put other motives in their place. It may over-task your bureaucratic machine, which the traditional individualism of the United States and the old "spoils system" have left none too strong. And it will confuse the thought and aim of yourself and your administration by giving you too much to think about all at once.

From here Keynes goes on to say that, from the other side of the Atlantic, it appears to him that during the first few months of the Administration, the relative importance given to the two policies is mistaken. In the fourth paragraph of the open letter he writes (emphasis added):

[I']m not clear, looking back over the last nine months, that the order of urgency between measures of Recovery and measures of Reform has been duly observed, or that the latter has not sometimes been mistaken for the former. In particular, I cannot detect any material aid to recovery in N.I.R.A., though its social gains have been large. The driving force which has been put behind the vast administrative tasks set by this Act has seemed to represent $a$ wrong choice in the order of urgencies... That is my first reflection - that N.I.R.A., which is essentially Reform and probably impedes Recovery, has been put across too hastily, in the false guise as being part of the technique of Recovery.

He approached this problem, as he usually did, using the Marshallian supply and demand apparatus. The challenge was to expand (aggregate) demand, and not to curtail supply. He emphasized this point: restricting output was the wrong thing to do; a curtailed supply results in higher prices, but also in reduced activity, incomes, and employment. In Keynes's words (paragraph six, emphasis added):

$[R]$ ising prices caused by deliberately increasing prime costs or by restricting output have a vastly inferior value to rising prices which are the natural result of an increase in the nation's purchasing power.

The problem, Keynes clarifies in paragraph seven, are not the social goals of the policies of reform. The issue is that an excessive and early emphasis on these goals may be misunderstood by the population. He writes:

I do not mean to impugn the social justice and social expediency of the redistribution of incomes aimed at by N.I.R.A. and by the various schemes for agricultural restriction. The latter, in particular, I should strongly support in principle. But too much emphasis on the remedial value of a higher price-level as an object in itself may lead to serious misapprehension as to the part which prices 
can play in the technique of recovery. The stimulation of output by increasing aggregate purchasing power is the right way to get prices up; and not the other way round.

\subsection{The exchange rate as the key link}

In the three full paragraphs strictly devoted to sequencing - paragraphs 2 through $4-$, Keynes does not specify the mechanism through which the Administration's policies were likely to affect its "prestige," and/or impact the degree of investors' "confidence." However, we can get some light about his thinking from other passages in the letter, and, in particular, from his criticism of FDR's exchange rate and gold-related policies. For Keynes, exchange rate stability was an important determinant of confidence. In paragraph 16 of the open letter he writes that an excessively unstable currency "upsets confidence, hinders business decisions, occupies the public attention in a measure far exceeding its real importance."

By 1933 Keynes's views on exchange rates and the international monetary system were already moving in the direction of what would later become the "Keynes Plan" discussed at the Bretton Woods Conference. ${ }^{31}$ He continued to be critical of the traditional gold standard, but he was not as scornful as he had once been. More specifically, the views on currencies presented in the 1933 pamphlet The means to prosperity, were quite different from those expressed a decade earlier in in A tract on monetary reform, where he wrote what became a famous quote: "In truth, the gold standard is already a barbarous relic... [I]n the modern world of paper currency and bank credit there is no escape from a 'managed' currency, whether we wish it or not..." ${ }^{32}$ In fact, in May 1933, a few weeks before the inauguration of the London Monetary and Economic Conference, Keynes proposed a new international system based on gold and relatively rigid exchange rates. What he had in mind, he wrote, was "a qualified return to the gold standard," where exchange rates would be stable, but could be changed if circumstances justified it.

From this perspective it is easy to understand Keynes's criticism of FDR's "gold buying” initiative in the open letter. According to this program, the Reconstruction Finance Corporation (RFC) was allowed to purchase gold at arbitrary prices determined daily by the Secretary of the Treasury and the President. ${ }^{33}$ The program was the brainchild of George F. Warren, a professor of agricultural economics at Cornell, who in a 1931 book (with Frank A. Pearson) concluded that there was a strict one-to-one relation between the price of gold and commodity prices. If the dollar was depreciated with respect to gold, the price of commodities would increase

\footnotetext{
${ }^{31}$ On the two competing plans considered at Bretton Woods, see Steil (2013).

32 Keynes (1923), p. 170.

33 There were two phases for the gold buying program. Generally, the second phase, which started in late October, is singled out as "the gold buying program." In spite of some superficial similarities, the Warren view differed significantly from Irving Fisher's "compensated dollar" proposal. Warren and Pearson (1933), p. 94.
} 
accordingly, and in a one-to-one fashion. On October 25, the first day of the gold buying program, the RFC paid \$31.36 per ounce of gold, 27 cents above the world price. During the days that followed, arbitrary prices were set daily by the President. On November 9, for example, the price was $\$ 33.15$ per ounce, 10 cents higher than the international market price. On November 15, an informed source stated that government had purchased modest amounts of gold internationally. In mid-December, by the time Keynes penned his letter, the RFC was paying $\$ 32.61$ per ounce of gold. These unpredictable "gyrations" of the dollar caused consternation among investors on both sides of the Atlantic. ${ }^{34}$

Keynes thought that Warren's theories were bogus and generated unnecessary noise in global financial markets. In paragraph 12 of the open letter he provides a scathing criticism of the principles behind the gold-buying program, without mentioning the Cornell professor:

It is... foolish... to believe that there is a mathematical relation between the price of gold and the prices of other things. It is true that the value of the dollar in terms of foreign currencies will affect the prices of those things which enter into international trade. In so far as an overvaluation of the dollar is impeding the freedom of domestic price-raising policies or disturbing the balance of payments with foreign countries, it was advisable to depreciate. But exchange rate depreciation should follow the success of your domestic price-raising policy as its natural consequence, and should not be allowed to disturb the whole world by preceding its justification at an entirely arbitrary pace.

In the same paragraph Keynes points out that excessive speculation in currency markets reduces the degree of "confidence" in the administration, and makes more difficult business decisions:

In the field of gold-devaluation and exchange policy the time has come when uncertainty should be ended. This game of blind man's buff with exchange speculators serves no useful purpose and is extremely undignified. It upsets confidence, hinders business decisions, occupies the public attention in a measure far exceeding its real importance, and is responsible both for the irritation and for a certain lack of respect which exists abroad.

But Keynes wants the president - and the public, for that matter - to understand that his criticism of the gold-buying program does not mean that he favors a return to the old gold, rigid standard. In paragraph 13 he writes: "These criticisms do not mean that I have weakened in my advocacy of a managed currency or in preferring stable prices to stable exchanges. The currency and

\footnotetext{
${ }^{34}$ See, NYT, "Fluctuations surprise the capital," November 10, 1933, p. 2
} 
exchange policy of a country should be entirely subservient to the aim of raising output and employment to the right level."

In the final chapter of The means to prosperity Keynes makes clear that his views about the international monetary system and exchange rates are fully consistent with expanding public works through loan-expenditures. The issue, he points out, is urgent, as "we have the task of putting at least 1,000,000 men back to work" (1933, p. 35). Achieving this goal, he states, is possible through a combination of an expansion of public works, and an exchange rate system that at the same time provides stability and frees central banks from their concern about "free gold.” Although the NYT open letter does not go into every detail of his plan to move the most important economies out of the Depression, it provides both a reaffirmation and an expansion of the views presented in the 1933 pamphlet.

In early May 1934, Keynes and his wife Lydia sailed to the United States in the USS Olympic. Columbia University had conferred on him an honorary degree, and the ceremony was to take place in New York City on June 5. While in the U.S. Keynes had meetings with a number of economists and policy makers, including Secretary of the Treasury Henry Morgenthau Jr., and Brains Trust member Rexford G. Tugwell. On Monday May 28, he finally saw President Roosevelt for an hour at 5:15 PM. ${ }^{35}$ According to Secretary of Labor Frances Perkins, the meeting was not a success. In her memoirs she writes that Roosevelt told her, "I saw your friend Keynes. He left a whole rigmarole of figures. He must be a mathematical rather than a political economist.” Immediately following the meeting Keynes visited Perkins in her office, and after stating that he admired Roosevelt's actions, he cautiously added that he had "supposed the President was more literate, economically speaking.”36

\section{Concluding remarks}

To finish, it is interesting to compare briefly Keynes's views on sequencing of policies with those developed in the 1980s and 90s. At that time, and as a result of the debt crisis in Latin America and of the collapse of the Soviet bloc, a large number of countries embarked on major economic changes. These reforms were aimed at reducing inflation, stabilizing the public accounts, opening up the economy to international competition, and deregulating goods and factor markets. Within this context, a number of authors, both in academia and in the multilateral institutions - the World Bank and the International Monetary Fund -, began to think about the most appropriate order of reform and liberalization.

\footnotetext{
${ }^{35}$ Skidelsky (1992, p. 506)

${ }^{36}$ Perkins (1946), p. 225-226.
} 
The question was whether these countries should proceed as fast as possible, making simultaneous progress on all fronts, or if, on the contrary, there was a particularly appropriate order of policy, where some goals were tackled first, and some postponed and/or pursued gradually. According to the IMF and the World Bank, there were two particularly pressing issues: the first one was whether macroeconomic stabilization should be pursued before structural reforms were put in place. In many ways this was similar to the problem addressed by Keynes in the open letter, except that in the 1990s the problems were high inflation and stifling regulations, while in 1933 they were deflation and cutthroat competition. The second major dilemma discussed in the 1980s and 90s had to do with the order of liberalization of the balance of payments: was it convenient to open up the trade and capital accounts simultaneously, or was it more appropriate to proceed step-by-step, and open trade before relaxing capital controls? This particular question was not tackled by Keynes in the open letter.

Within a short period of time, a substantial literature developed on the subject of policy dynamics, policy transition, and sequencing - see for example McKinnon (1982, 1993), Edwards (1990), Krueger (1986), Mussa (1986), and Mundell (1995). Although none of the many authors who wrote on the subject referenced the New York Times open letter, many of them followed an approach that had a number of similarities to that developed by Keynes. In particular, most of this literature emphasize the political economy angle, and argued that in order to be sustained through time, it was fundamental that the reforms got supported by the public and voters. Support, in turn, depended on the sequencing of policy. The appropriate order was the one that generated "confidence" in the transformation program. As Keynes had done more than five decades earlier, the exchange rate was considered to be the key variable in this process. A stable and competitive real exchange rate was necessary for generating credibility; in contrast, a volatile and overvalued currency would, more often than not, result in a failed reform process

Most modern authors argued that in countries with very high inflation and a situation of "monetary overhang" - most nations the former Soviet bloc -, it was necessary to allow prices to adjust quickly and in a once and for all fashion. This meant that macroeconomic stabilization had to be pursued first, and very fast. Within this process it was important that central banks stopped printing money to finance the government deficit. Thus, a market for government debt had to be developed. An implication of this was that jointly with the price adjustment (or soon after) interest rates had to be liberalized and allowed to reflect the true scarcity of funds. Once these two policies were in place, scarcity and black markets would be eliminated and inflation would abate, providing relief to the population and support to the reformist government.

The second point emphasized in the modern literature was that an early relaxation of capital controls was likely to generate major dislocations in the foreign exchange market. In many cases relaxing controls meant a sudden and very large inflow of capital. This, in turn, would trigger a 
major appreciation of the real exchange rate. Speculation and a trade deficit would follow. At the end, it was argued that situation would become unsustainable and a crisis would erupt. At that point trade barriers would be imposed, and the reforms would be reverted. The practical point was that the adequate order of policy called for a delayed and gradual relaxation of capital controls. By emphasizing the key role of the exchange rate in programs of deep economic transformation, literature of the 1980s and 1990s was remarkably Keynesian. ${ }^{37}$

${ }^{37}$ In later years the literature on sequencing moved in two directions: attempts were made to develop fully optimizing general equilibrium models to analyze the welfare consequences of alternative orders of reform. Also, DSGE models were used to simulate the effects on different variables - income, employment, and wages - of alternative sequences. 


\section{References}

Acheson, D. (1965). Morning and noon. Houghton Mifflin.

Ahamed, L. (2009). Lords of Finance: The bankers who broke the world. Random House.

Bloomfield, A. I. (1950). Capital Imports and the American Balance of Payments, 1934-39. A Study in Abnormal International Capital Transfers. University of Chicago Press.

Dimand, R. W. (1994). "Irving Fisher's Debt-Deflation Theory of Great Depressions.” Review of Social Economy, 52(1), 92-107.

Edwards, S. (1990). "The sequencing of economic reform: Analytical issues and lessons from Latin American experiences.” The World Economy, 13(1), 1-14.

Edwards, S. (2107a), “Gold, the Brains Trust and Roosevelt,” History of Political Economy, Winter.

Edwards, S. (2107b), "The London Monetary and Economic Conference of 1933 and the end of the Great Depression,” Open Economies Review, July

Edwards, S. (2107c), “Keynes and the dollar in 1933” Financial History Review, December

Edwards, S. (2018), American Default: The untold story of FDR, the Supreme Court and the battle over gold. Princeton: Princeton University Press.

Eichengreen, B. (1992). Golden fetters. Oxford

Feis, H. (1966). Characters in Crisis. Boston, Toronto: Little1, Brown, and Company.

Felix, D. (1999). Keynes: A critical life (No. 208). ABC-CLIO.

Freedman, M. (1967). Roosevelt and Frankfurter: their correspondence, 1928-1945/annotated by. Boston: Little, Brown, 1967.

Friedman, M., \& Schwartz, A. J. (1963). A monetary history of the United States, 1867-1960. Princeton University Press.

Galbraith, J. K. (1984). "Keynes, Roosevelt, and the complementary revolutions.” Challenge, 26(6), 4-8.

Harberger, A. (1986). “A primer on the Chilean economy.” Choksi and D. Papageorgiuous (Eds.), Economic Liberalization in Developing Countries, Blackwell, Oxford.

Harrod, R. F. (1951). Life of John Maynard Keynes. Macmillan

Hausman, J., P. Rhode, and J. Wieland (2016). "Recovery from the Great Depression: The farm channel in Spring 1933,” University of Michigan. 
Keynes, J. M. (1923). A tract on monetary reform. Macmillan.

Keynes, J. M. (1930). A treatise on money. Macmillan.

Keynes, J. M. (1933). The means to prosperity. Macmillan.

Keynes, J. M. (1933). "From Keynes to Roosevelt: Our recovery plan assayed,” The New York Times, January 31, 1933, p. 2 XX.

Keynes, J. M. (1982). Activities 1931-1939, World Crises and Policies in Britain and America, Volume XXI of the Collected Writings of John Maynard Keynes. JMK XXI. Moggridge (ed), London, Macmillan and Cambridge University Press for the Royal Economic Society.

Kindelberger, C. P., (1978). Crashes: A History of Financial Crises. Basic, New York.

Kroszner, R. (1999). Is it better to forgive than to receive?: Repudiation of the gold indexation clause in long-term debt during the great depression. Center for Research in Security Prices, Graduate School of Business, University of Chicago.

Krueger A.O. (1986). "Problems of liberalization.” Choksi, A. M., \& Papageorgiou, D. (Eds.). Economic liberalization in developing countries. Blackwell.

Lash, J. P. (1975). From the diaries of Felix Frankfurter. New York: Norton.

Leith-Ross, F. (1968). Money talks: fifty years of international finance: the autobiography of Sir Frederick Leith-Ross. Hutchinson

Markwell, D. J. (2000). Keynes and Australia. Sydney: Reserve Bank of Australia.

McKinnon, R. I. (1982). "The order of economic liberalization: lessons from Chile and Argentina.” In Carnegie-Rochester Conference Series on Public Policy (Vol. 17, pp. 159186). North-Holland.

McKinnon, R. I. (1993). The order of economic liberalization: Financial control in the transition to a market economy. JHU Press.

Meltzer, A. H. (2003). A History of the Federal Reserve, Vol. 1 Chicago.

Moggridge, D. (1992). Maynard Keynes: an economist's biography. Routledge.

Moley, R. (1939). After seven years. Harper \& Bros.

Moley, R. (1966). The First New Deal. Harcourt.

Morgenthau Jr., H. “Farm Credit Diary.” The Morgenthau Papers at the Roosevelt Presidential Library. 
Mundell, R. (1995). "Stabilization and liberalization policies in semi-open economies.” In S. Edwards (Ed.), Capital Controls, Exchange Rate and Monetary Policy in the World Economy.

Mussa, M. L. (1986). “The Adjustment Process and the Timing of Trade Liberalization.” In A. Choksi and D. Papageorgiou, eds., Economic Liberalization in Developing Countries. Oxford: Blackwell.

New York Times, The. Several issues.

O'Connell, J. (2016). “On Keynes on inflation and unemployment.” The European Journal of the History of Economic Thought, 23(1), 82-101.

Pasvolsky, L. (1933). Current monetary issues. Brookings Institution

Perkins, F. (1946). The Roosevelt I Knew. New York: Viking.

Rauchway, E. (2015). The Money Makers: How Roosevelt and Keynes Ended the Depression, Defeated Fascism, and Secured a Prosperous Peace. Basic Books.

Reinhart, C. M., \& Rogoff, K. S. (2009). This time is different: Eight centuries of financial folly. Princeton University Press.

Roosevelt, F.D. (1938). Public Papers and Addresses of Franklin D. Roosevelt. Random House

Sachs, A. (1934), "National Recovery Administration policies and the problem of economic planning,” In America's Recovery Program, Edited by A.A. Berle et. al. Oxford University Press, 1934.

Skidelsky, R. (1992). John Maynard Keynes. Vol. II: The Economist as Savior, 1920-1937.

Steil, B. (2013). The battle of Bretton Woods: John Maynard Keynes, Harry Dexter White, and the making of a new world order. Princeton University Press.

Sumner, S. (1999). "The role of the gold standard in Keynesian monetary theory.” Economic Inquiry, 37(3), 527-540.

Sumner, S. (2015). The Midas Paradox. Washington D.C.: Independent Institute

Temin, P. (1976). Did monetary forces cause the Great Depression?. New York: Norton.

Times, The (London), Several Issues

Tugwell, R. G. (1952, 1932-1935). The Diary of Rexford G. Tugwell: The New Deal, 1932-1935 Edited by M.C. Namorato (No. 136). Greenwood Pub Group

Tugwell, R. G. (1968). The Brains Trust. Viking Adult. 
Tugwell, R. G. (1970). “Roosevelt and Frankfurter: An Essay Review.” Political Science Quarterly, 85(1), 99-114.

Warburg, J. P. (1934). The money muddle. Knopf.

Warburg, J. P. (1964). The Long Road Home: The Autobiography of a Maverick. Doubleday.

Warren, G. F., \& Pearson, F. A. (1931). Prices. Wiley

Warren, G. F., \& Pearson, F. A. (1935). Gold and prices. Wiley 